\title{
CLÍNICA E VIRTUALIDADE: ENCONTROS COM O IMPESSOAL
}

\author{
Patrícia Beatriz Argôllo Gomes Kirst \\ Universidade Federal do Rio Grande do Sul, Porto Alegre, Brasil
}

\section{Resenha: ARAGON, L. E. P. (2007). O impensável na clínica: virtualidades nos encontros clínicos. Porto Alegre: Sulina/UFRGS.}

O livro de Luis Eduardo Aragon propõe um encontro com o leitor que vai se desdobrando em vários encontros. É através da apreciação de alguns casos clínicos que a afecção vai se construindo com uma intensidade de variações que caminham para pensar a clínica contemporânea como inclinação para entradas, para além do inconsciente: entradas no campo do impessoal. A possibilidade da inauguração de momentos nas virtualidades e potências criativas do impessoal são indicadas pela sensação no encontro clínico: tal é o território da invenção, pois nele tudo foge de determinação e Lei. E o livro é assim, é nascedouro de sensações no compartilhamento de cartografias clínicas que vão sendo apresentadas inteligentemente em rizoma e desmesura.

Produzir, uma clínica principalmente, pelo prazer do jogo e por desfrutar a presença do outro que deixará um rastro e, portanto, algo do impessoal. Esse conceito nos transporta para um tema importante do pensamento de Deleuze, o impessoal no qual expressa a ideia do sujeito em dispersão, fazendo-nos migrar da vida do individuo para o espaço molecular de onde proliferam singularidades no acesso do pré-individual e do présubjetivo. É o plano do "se": pensa-se, faz-se, morre-se na indicação de uma quarta pessoa do singular que está no campo de indeterminação entre uma imagem e outra, entre um pensamento e outro. Esta voz da quarta pessoa do singular da qual ninguém fala e que insiste em cada ato de criação não se transforma em expressão porque, quando expressão, já não pertence mais ao interstício ou "intermezzo" dos sentidos.

A análise das formas de diagnóstico contemporâneas relacionadas com platôs tecnológicos que desterritorializam o olhar e o fazem ver através do corpo podem trazer molecularidades de falência de sentidos anteriores a qualquer sensação de doença. A ordem é inversa: primeiro o diagnóstico, depois a doença. Então, como lidar com um virtual que se atualiza primeiro no olho blindado de uma máquina em seus avessos hiperespecializados? A produção de "seres imagéticos", segundo as palavras do autor, pode variar, desde ver a face do bebê no útero, seu sexo, até doenças que virão a se manifestar e mostrar certa entrada no trágico em um tempo que virá. Portanto, ao lidar com este olhar tecnológico hiperpenetrante, o próprio estatuto da clinica adentra em fronteiras da dimensão do sentido de vida e morte. Agonias impensáveis advêm hoje de uma esfera virtual do corpo que se apresenta como desafio e fonte de sentido para o corpo-pensamento. A tentativa de constituição de cenários e afecções nestas fronteiras complexas e atravessadas por agenciamentos do sofrer e do viver são os focos éticos e políticos da obra de Aragon e suas possibilidades férteis enquanto analista, médico, técnico, cidadão, pensador e um de nós na aventura de transcender certos sentidos da vida em agonia e reinvenção no contemporâneo.

Estamos tratando de sair dos meandros do paciente e do cuidador universais para afirmar que, nesse encontro, ambos os papéis se misturam e interpelam, tentando dar passagem à novidade de habitar o tempo do instantâneo e da velocidade. Vê-se a dobra do corpo com uma nitidez jamais experimentada e, é claro, tal fato redimensiona a anamnese, a escuta e relação clínica de forma definitiva. O barco da clínica é tensionado pelas ondas de um olho afirmativo e irrefutável e um olho nômade e repleto de sensações indizíveis e pregnantes de imagens que transbordam também de silêncios. Sabe-se tanto de tantas instâncias que um diagnóstico vai transitando em compartimentos oncológicos, cardiológicos, ecocardiológicos, fisiológicos, psicológicos e em tantos lógicos quanto o corpo puder ser aberto e circunscrito.

Os profissionais da clínica carregam o tempo da velocidade com várias frentes de trabalho, vários pacientes, várias famílias buscando respostas e saídas, e cronologia exígua para dar conta de corpos em pedaços. Entretanto, o que a doença pode sugerir é um espaço de retomada da reinvenção existencial: é o momento de ter de lidar com o impensado, o não saber, a raiva, o medo e a marca de um acontecimento. Aqui o conceito de acontecimento é entendido segundo Foucault (1984), sempre uma ruptura evidente - a emergência de uma singularidade - e, ao mesmo tempo, uma ruptura de evidências. Falamos, pois, de uma clínica-acontecimento que, irrevogavelmente, remete-nos a uma problematização. Ou ainda, em Foucault (1992, p. 28), o acontecimento pode ser compreendido como

(...) não uma decisão, um tratado, um reino, ou uma batalha, mas uma relação de forças que se inverte. As for- 
ças que se encontram em jogo na história não obedecem uma destinação, nem a uma mecânica, mas são ao acaso desta luta. É preciso entender este acaso não como um simples sorteio, mas como o risco sempre renovado da vontade de potência que a todo surgimento do caso opõe, para controlá-lo, o risco de um acaso ainda maior.

Assim, para além da produção de resultados objetivos, nossas práticas podem indicar em que direção estamos orientando o nosso desejo de transformação, enfim, nelas se explicitam em que nos estamos tornando.

Acreditamos que a clínica corresponde a fazer renascer o objeto, vida-morte, saúde-doença, livrando-o sutilmente dos discursos anteriores e inaugurando-o através de nova estética argumentativa. É preciso criar acoplamentos e diálogos entre linguagens, inventar e ativar conexões, enfim, constituir uma rede de múltiplas reverberações. O livro promove e é testemunho dessa aposta.

\section{Referências bibliográficas}

Deleuze, G. (1988). Diferença e repetição. Rio de Janeiro: Ed. 34. Deleuze, G. (1991). A dobra. Leibniz e o barroco. Campinas, SP: Ed. Papirus.
Deleuze, G. (1992). O que é filosofia? São Paulo: Ed. 34.

Deleuze, G. (1997). Crítica e clínica. São Paulo: Ed. 34.

Deleuze, G. (1999). Bergsonismo. São Paulo: Ed. 34.

Foucault, M. (1992). As palavras e as coisas: uma arqueologia das ciências humanas. São Paulo: Martins Fontes.

Patrícia Beatriz Argôllo Gomes Kirst é Psicóloga, Mestre em Psicologia Social e Institucional/UFRGS, Docente e Membro da Equipe de Coordenação do curso de Pós-Graduação/ Especilização em Psicologia Social e Institucional/ ESADE, Doutoranda do Programa de PósGraduação em Informática na Educação/UFRGS. Endereço para correspondência: R. Aurélio Bittencourt,150/302. Bairro Rio Branco. CEP 90430-080. POA/RS. Email: pgomes.voy@terra.com.br

Clínica e virtualidade: encontros com o impessoal Patrícia Beatriz Argôllo Gomes Kirst

Recebido em: 22/04/2008

Revisão em: 20/10/2008

Aceite final em: 3/11/2008 